\title{
Venture Capital Financing: Perspective of Entrepreneurs in an Emerging Economy
}

\author{
Charles Adusei \\ Department of Accounting, Banking and Finance, \\ Faculty of Business Studies, Garden City University College. Kumasi, Ghana \\ Tweneboah-Koduah Isaac \\ Department of Managerial Sciences, \\ Faculty of Business Studies, Garden City University College, Kumasi, Ghana
}

\begin{abstract}
In the developing countries the need for capital of small businesses remains small and fragmented despite a vast number of small businesses operating in these countries. A cross-sectional survey of entrepreneurs was conducted within the Kumasi Metropolis of Ghana on their perspective of venture capital financing. Questionnaires were used to assess their perception and impact of venture capital financing on small businesses whiles descriptive statistics and multiple linear regression were used to analyse the data. Result revealed that the requirement for accessing venture capital was difficult and cumbersome but the entrepreneurs confirmed that venture capital financing and its related packages can make the enterprise a success. The study found sales, innovation and efficiency variables to be positively significant whiles profit has a negative significant impact on venture growth and performance. This study suggests that the venture capital trust fund must embark on nationwide educational drive by engaging the business communities on its operations. The government must show real commitments and programmes towards the realisation of private enterprises development. Furthermore, the study prescribed five generic requirements for entrepreneurs and the venture capital industry that will guide start-up businesses.
\end{abstract}

Keywords: Entrepreneurs, Venture Capital Financing, Venture Capital Trust Fund, Ghana

\section{INTRODUCTION}

One of the dreams of any entrepreneur is to build a winning business whether it is for existing one or what the entrepreneur has in his/her plans and hope he/she will get it right one day. McKaskill [1] indicated that entrepreneurs are optimists and the society is fortunate that they are prepare to risk their savings and time to have a business because without their drive, creativity and perseverance, many of today's large corporations would not be in existence.

Butler [2] stressed that enterprise is the term that is generally applied to small or mediumsized business. He went on to say that an enterprise can be a start-up; an early stage business or equally developed business. Hatten [3] affirms that entrepreneurs are people who start enterprises or business; he describes a serial entrepreneur as one who is into the creation of new businesses for the purposes of selling it for profit. Longnecker et al., [4] affirmed that an entrepreneur who creates and operates an enterprise is displaying the characteristics of entrepreneurship. Small enterprises encompass a variety of businesses and sectors, ranging from relatively stable businesses looking to expand, to companies that leverage innovation to transform an existing market as asserted by Divakaran et al., [5] Contribution by the small businesses to the economy of any country cannot be underestimated in terms of job creation, payment of taxes, serving as the breeding ground for entrepreneurs to build larger businesses and investment generating center for many investors. It is strange that much has not being 
done by many governments, financial institutions and private equity firms to develop such an important sector of the economy.

Lack of finance has been regarded as one of the major problems contributing to slow development and high mortality rates of small businesses in developing economies as indicated by Muteti [6]. Small businesses have made use of micro credit from the microfinance institutions to run their businesses, which offer most of the time small and short-terms loans. This avenue has outlived its purpose from the small businesses point of view as the size and credit demands of their businesses have also outgrown the capacity of microfinance institutions. The traditional option of external financing to many small businesses and entrepreneurs is bank lending. OECD [7] asserted that small businesses often heavily rely on straight debt to fulfill their start-up, cash flow and investment needs. While it is commonly used by small businesses, however, traditional bank finance poses challenges to small businesses and may be ill-suited at a specific stage in the firm's life cycle.

Several governments have come and gone employing certain schemes such as Business Assistance Fund, Ghana Investment Fund and Export Development and Investment Fund in the 1990's and 2002 to support small and medium-size enterprises in the areas of financing and seminars/workshops to manage their businesses better. These schemes had its own challenges hence the Venture Capital Trust Fund (VCTF). The VCTF was established in 2004 through an Act of Parliament (VCTF Act 680). The fund's intention is to provide low cost financing to small and medium enterprises so as to enable them expand, create wealth and jobs. It does this by providing credit and equity financing to eligible Venture Capital Finance Companies to support Small and Medium Enterprises (SME's).

Abor and Quartey [8] established that many entrepreneurs cannot provide the preferred collateral acceptable by the banks. This means that venture capital finance would be more suitable than debt finance for those who cannot meet the banks requirements. Landstrom [9] indicated that financing problems goes beyond the supply-side issues as his study revealed that many SME's especially small firms, are not aware of the available financing possibilities, and even if they are, they do not know how to approach it. The results from such study point to a need for initiatives that raise the awareness of financing possibilities among firms. Considering the roles of the SME's and its impact on the economy it is difficult to accept that financing gap is still a major issue for entrepreneurs and SME's in general. Is it because the authorities think that it is not significant enough or they do not have the clout to make things happen or really they are not in need of financial support from the governments or the government commitment is just a rhetoric? In finding solutions to the questions raised the study delved into the perceptions of entrepreneurs on venture capital financing as an alternative form of equity financing and its impact on their business activities. Section 2 surveys related studies on venture capital financing. Section 3 contains a description of the data and methodology. In Section 4, the results and discussions of the study are provided, while Section 5 concludes the paper.

\section{WHAT DOES THE LITERATURE SUGGEST?}

The society needs growth-oriented entrepreneurial ventures as they create innovations and dynamics, new jobs, income and not the least, wealth as stressed by Landstrom [9]. He further indicated that venture capital is a significant vehicle for promoting their growth. The importance of venture capital makes it essential to understand the way the venture capital market operates, and how business angels and venture capitalists manage their investments. Bürgel et al., [10] found that only around 1 in 10 of United Kingdom (UK) firms had received venture capital. In Germany, this ratio went down to 1 in 14. Even in the United States (US), 
Auerswald and Branscomb [11] noted that the supply of institutional venture capital finance for technology development trails significantly behind business angels, corporations and the Federal Government. It is salutary to note that in 2005, the US and UK venture capital industries invested collectively in only 412 seed and start-up deals according to BVCA, [12]. This is from two major world economies where, collectively, over one million new businesses are started every year. Thus, institutional venture capital still remains a specialist financing instrument of relevance only to a tiny percentage of the population of new and growing enterprises in any economy.

Despite the assumption that venture capital is a suitable subject for policy action, surveys of SME finance repeatedly show that entrepreneurs' receipt of risk capital from professional investors is an extremely rare event. Reynolds et al., [13] 'guesstimate' that less than half a per cent of all nascent entrepreneurs receive either venture capital or business angel finance at start-up. A 2004 survey of UK SMEs showed that less than 2 per cent of respondents had ever raised institutional venture capital as stated by Small Business Service [14] A similar percentage has been recorded in Europe (European Commission, [15]). Given that the UK has the largest and most advanced venture capital/private equity industry in Europe, it is probable that other countries are unlikely to register significantly greater risk capital activity among their young firms. European studies confirm this reality of the scarcity of venture capital receipt (European Venture Capital Association, [16]). Divakaran et al., [5] indicated that the lack of venture capital for small businesses in developing economics goes beyond simply limiting the access to capital of these businesses but not getting investor's knowledge and know-how to the businesses if they had invested in them. They went on to stress that though private equity investment could help to create, deepen, and expand small businesses growth in developing economies but the vast majority of private equity firms in such markets targets larger or more established enterprises.

A study conducted by Alemany and Marti [17] on unbiased estimation of economic impact of venture capital backed firms in Spain between 1993-1998 using 323 Spanish firms and a control sample similar without venture capital backed firms. The study revealed that venture capital backed companies had a greater economic impact and that venture capital funding had a significant and positive effect on growth in employment, sales, gross margin, total assets, net intangible assets and corporate tax paid. It was revealed that venture capital backed firms reported high growth sales than non-backed venture capital firms as declared by Bloomfield [18].

Gans and Stern [19] found that venture capital financing strongly impinge on firm's innovation, patenting processes and the influx of technological opportunities. This is the unique way to extract the social significance of an innovation. Hence, triggering innovations, along with the firm's professionalization, is another valuable feature of the venture capital funding. Engel and Keilbach [20] suggested that venture capital financing firms showed high profitability than non-backed venture capital financing in a study conducted in Germany. Hellmann and Puri [21] affirmed that venture capitalist brings about professionalism and value adding activities due to his/her involvement in the business as equity holder of the business.

Several authors have reported on the positive effects of venture capital financing on businesses from different perspectives. Peneder [22] affirmed productivity, innovation and strategy formation and its implementation by venture capital financing firms. Hellmann and Puri [21] (2002) asserted that increase in professionalism in business operations enhances internal control and credibility from relevant stakeholders. Caselli et al., [23] indicated that innovation 
in terms of productivity and creation of patent are added benefits of venture capital financing. Venckuviene, [24] declared that there exist a relationship between venture capital investments and innovation strategy. Kelly and Hankook [25] established that there is empirical evidence suggesting that venture capital is associated with faster growth and an acceleration of the innovation and commercialization process.

Authors such as Chemmanur et al., [26] and Kelly and Hankook [25] in their studies investigated on how venture capital financing has positive effect on companies' sales and employment growth. Chemmanur et al., [26] indicated that overall efficiency gains generated by venture capital backing arise primarily from improvements in sales, the efficiency gains of high-reputation venture capital backed firms arise also from lower increases in production costs. Kelly and Hankook [25] confirmed that venture capital backed firms outperform their non-venture capital backed counterparts in terms of growth indicators such as higher growth in sales, wages, and employment. Delmar et al., [27] affirmed that sales are one of the preferred indicators as a performance measure of firm's growth. Sales figures are relatively easy to obtain and reflect both short term and long-term changes in the firm.

Markman and Gartner [28] stressed that it is not strange that growth has been used as a measure of firm performance to the attainment of sustainable competitive advantage and profitability. Delmar et al., [27] pointed out that firm growth is not static in nature and there may be considerable variation in firm growth over time. They went on to argue that firm's growth pattern is related to age, size and industry. Cowling [29] investigated the relationship between growth and profitability and found little evidence of the growth versus profit tradeoff. He suggested that there is potential for a cumulative type effect whereby profits engender growth and growth engenders future profit that allows some firms to continually face increasing returns to scale. It can be infer that in order to finance growth, the firm must forego profits.

\section{Study Area}

\section{STUDY AREA AND METHODOLOGY}

The population of Kumasi Metropolis is 1,730,249 represents 36.2 percent of the total population of Ashanti Region, from the 2010 Population and Housing Census. The Metropolis has a total number of 440,283 households with an average household size of about 4 persons. The percentage of population aged 11 years and older who are literate is 89.5 percent while 10.5 percent are not literate. About 66.5 percent of the population aged 15 years and older is economically active while 33.5 per cent is economically not active. Of the economically active population, 91.4 percent is employed while 8.6 percent is unemployed. Of the employed population, 38.9 percent are in the service and sales work, 22.8 percent are in craft and related trades 10.3 percent are into elementary occupation and only 2.6 percent are skilled agricultural forestry and fishery workers. Females (55.1\%) are more likely than males (22\%) to be engaged in service and sales work whereas males $(32.9 \%)$ are more likely than females $(13.1 \%)$ to be engaged as craft and related trade. About 49.2 percent of the workforce is selfemployed without employees with females and males proportions as 60.1 percent and 37.9 percent respectively as indicated by Ghana Statistical Service [30].

\section{Methodology}

The study adopted descriptive cross-sectional study in a survey form which investigated entrepreneurs' perception of venture capital financing as an alternative source of finance within the Kumasi Metropolis of Ghana, especially those with knowledge of venture capital financing or with prior experience of venture capital financing. As indicated by De Vaus, [31], a survey research uses structured and in-depth interview, observation and content analyses 
apart from questionnaires that are widely used.

Bethlehem [32] indicated that a target population of a study is the population that should be investigated. It is also the population to which the outcomes of the survey refer. He went on to say that the elements of a target population are often people, households or companies. The population of the study covers all entrepreneurs with prior experience with venture capital trust fund or have knowledge on venture capital financing. The Association of Ghana Industries (AGI) indicated that not many of its members in the Kumasi Metropolis have made use of the venture capital trust fund. The population includes all entrepreneurs within the Metropolis.

Two-Stage sampling approach was employed for the study. The first of which was the purposive selection of Kumasi Metropolis as a district among two hundred and sixteen districts from ten administrative regions. This was chosen based on the proximity and knowledge of the town by the author. The entrepreneurs' preparedness and voluntary participation was a factor for the study area. The second stage was using quota target for the selection of the entrepreneurs which was purposively done. The sample size of fifty (50) entrepreneurs who had membership registration with Association of Ghana Industries (AGI) was used for the study. The determination of sample size was non-statistical; it was based on the availability of the right respondents who have a fair knowledge of the issues under discussion. Most importantly the respondent should be voluntarily ready to be part of the study.

Questionnaires were used to solicit information from the entrepreneurs. The questionnaire was in the form of five likert scales. The questionnaire was divided into three (3) main sections, with each section examining different issues in the study. Section I looked at Sociodemographic characteristics of entrepreneurs. Section II explores the perception on venture capital financing. Section III examined the impact of venture capital financing on small businesses. A self-administered questionnaire was used to gather information from the entrepreneurs through drop-and-collect technique. This involved leaving a questionnaire with a respondent and going back to pick it up. This was used due to educational level of the entrepreneurs as they have the knowledge and ability to fill the questionnaire. The selfadministered questionnaire helped to avoid the interviewer's bias and moreover gave the study the opportunity to ask a bit more complex questions. Another advantage is that it gave the respondents plenty time to consider their answers as compared with the interviewing technique where the interviewee required an immediate response.

Field [33] indicated that a questionnaire should consistently reflect the construct that it is measuring to determine its reliability. Leech et al., [34] stressed that the value of Cronbach Alpha should be equal to or greater than 0.70 . Whenever a scale is used for a study, it is important to find out that the scale is reliable. This has to do with the scale's internal consistency. The Cronbach's alpha coefficient were $0.968(n=7)$ and $0.939(n=5)$ respectively for entrepreneurs' perception of venture capital financing and impact of venture capital financing which were above 0.70 which is normally acceptable by researchers as a good reliability of a scale to indicate its internal consistency.

\section{ANALYTICAL FRAMEWORK}

Descriptive statistics such as frequency and percentages were employed to analyse data used to present the socio-economic characteristics of the entrepreneurs and entrepreneurs' perception on venture capital financing. 
In addition the study made use of multiple regression analysis to establish the relationship and the significance of the independent variables on venture growth and performance of small businesses as part of venture capital financing. The regression equation is stated as:

$$
\mathrm{VG}=\beta_{0}+\beta_{1} P F T+\beta_{2} I N N+\beta_{3} S A L+\beta_{4} E F T+\varepsilon_{t}
$$

Where $\beta_{0}$ represents the constant of the intercept and $\varepsilon_{t}$ is the error term. VG is the dependent variable which represents venture growth and performance. Improved profitability, enterprise innovation, high growth sales and increase efficiency are represented by PFT, INN, SAL and EFT respectively. The independent variables are expected to have a positive relation with venture growth and performance.

Hypothesis of the study were constructed as follows:

Ho$_{1}$ = Profitability has an insignificant impact on venture growth and performance

$\mathbf{H o}_{2}$ = Innovation has an insignificant impact on venture growth and performance

$\mathbf{H o}_{3}=$ Sales have an insignificant impact on venture growth and performance

$\mathbf{H o}_{4}$ = Efficiency has an insignificant impact on venture growth and performance

\section{Variable description}

\section{Dependent variable}

Venture growth and performance (VG): This is basically how venture capital financing maintain and speed up the small enterprises growth and its performance. Growth is a onedimensional construct operationalized by a variety of growth measures like sales, profit, number of workers, value of net assets and market share among others.

\section{Independent variables}

Profit (PFT): Profitability is a yardstick by which entrepreneurs can measure their achievements and justify their claims to compensation. This assessed how the injection of venture capital financing has made the enterprise more profitable. Profitability is assumed to have a relationship with growth of an enterprise hence entrepreneurs who make higher profits are more likely to grow their enterprises. It is therefore hypothesised that venture capital financing that leads to improve profitability is positively related to the growth and performance of venture.

Innovate (INN): Innovation is the ability to process an idea or invention into a good or service for which others will be prepared to purchase because it creates value for the buyer. Small enterprises will typically invest much less, if at all in research and development vis-a-vis its limited human and financial resources. This assessed how venture capital financing impinges on enterprise's innovation. Innovative entrepreneurship is basically where an entrepreneur builds a new business from the beginning on a completely new idea within an existing environment to solve a problem. It is hypothesised that venture capital financing impinges on innovation hence venture capital financing which leads to innovation is positively related to the growth and performance of the venture.

Sales (SAL): Sales volume equals the quantity of goods/services a business sells during a given period of time such as monthly, quarterly or yearly. Sales or sales revenue equals the Ghanaian Cedis amount a business makes during a period. This assessed how venture capital financing injection improves sales or revenue in order to attain growth. It is hypothesised that venture capital financing will improve sales due to the professionalism investors brings to bear on the business hence venture capital financing which leads to improve sales is positively related to the growth and performance of the venture. 
Efficient (EFT): Efficiency is one of the top priorities if businesses are to thrive and grow. Without efficient systems in place, each phase of growth will only cause more issues. Here the concern is operational efficiency. This assessed how venture capital injection increases efficiency and reduces waste in enterprises. It is hypothesised that venture capital financing will improve operational efficiency due to regulations, compliance and professionalism venture capitalist brings to bear on the business hence venture capital financing which leads to operational efficiency is positively related to the growth and performance of the venture.

\section{Ethical consideration}

The study followed all ethical practices during the research. The entrepreneurs were made aware of the purpose of the study before the data collection process. They were assured of their privacy and anonymity of their responses hence their names were not published in this study and their participation was voluntary.

\section{RESULTS AND DISCUSSION}

This section discusses the demographics of the entrepreneurs, entrepreneur's perception of venture capital financing and the impact of venture capital financing on businesses.

\section{Demographic information of respondents}

The questionnaire data were collected from fifty entrepreneurs of whom thirty-eight were males whiles twelve were female. This confirms that there are more males entrepreneurs as compare to females in Kumasi Metropolis. Their ages ranged from twenty-nine to fifty-five, with an arithmetic mean of forty-two years. Out of the fifty entrepreneurs ten, twenty-three and seventeen were into manufacturing, service and commerce respectively. This indicated that majority of small businesses in Kumasi can be categorized as service oriented businesses. In terms of employment, thirty-three out of the fifty entrepreneurs have employed maximum five workers while eleven have maximum ten workers. Four entrepreneurs had maximum fifteen workers whiles two entrepreneurs had maximum of twenty workers to support their business operations. Twenty-seven of the entrepreneurs years of business activities spanned between two years and ten years whiles eighteen entrepreneurs had eleven and twenty years. The other five entrepreneurs had twenty-one and thirty years of business activities.

Figure 1. Entrepreneur's perception of venture capital financing

\section{Entrepreneur's Perception of Venture Capital Financing}

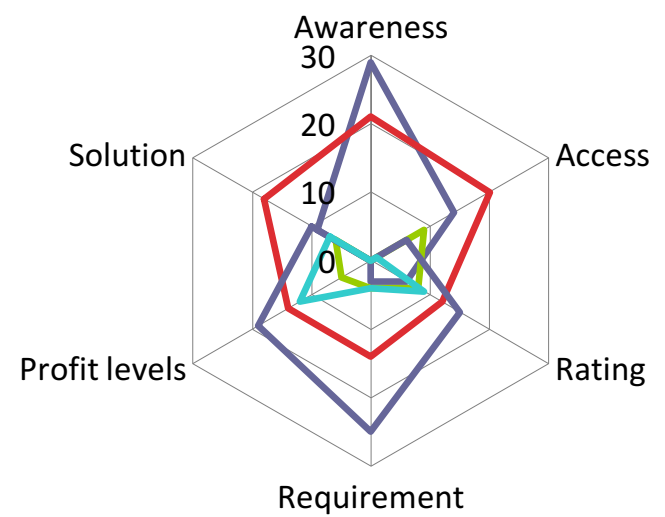

Source: Field data, 2017 


\section{Entrepreneur's Perception of Venture Capital Financing}

The entrepreneurs' perception of venture capital financing was evaluated using five likertscales. Figure 1 indicates the absolute numbers of the entrepreneurs' responses on the six thematic areas to find out their perception of Venture Capital Financing in Ghana. The reporting was done using the corresponding percentage of the absolute number.

Awareness as indicated under Figure 1 mean that the entrepreneurs might be aware of venture capital financing through the Venture Capital Trust Fund (VCTF) and its allied companies or not. Twenty-nine entrepreneurs representing 58\% declared that they have a fair knowledge of the activities VCTF which goes beyond just the awareness level of venture capital financing whiles twenty-one entrepreneurs constituting 42\% indicated that they were aware of the existence of venture capital finance as a source of finance that an entrepreneur can access. With the majority (58\%) of the entrepreneurs having a fair appreciation of the VCTF and its operations meant that they were not ignorant about venture capital as an alternative source of equity financing. Entrepreneurs were asked given the opportunity would they be prepared to always access the venture capital financing for their businesses. It was a mixed reaction from them as $68 \%$ reported that they will be glad to access the fund with $18 \%$ indifferent on the theme and $14 \%$ indicated that they would not access the funds. Availability of other alternative funds was the defense of those who declared they would not access the fund. This was in line with the findings of Burgel's [10], who indicated that there are several ways by which businesses can raise capital to finance working capital and expansions. Contrary Landstrom [9] stressed that many small businesses were not aware of available financing possibilities, and even if they were, they did not know how to approach it.

Rating has to do with credit rating assessment of financial intermediaries on entrepreneurs who accessed venture capital financing as perceived by the entrepreneurs. $36 \%$ of the entrepreneurs indicated confidently and in affirmative that it can boost the business credit rating whiles $48 \%$ of the entrepreneurs though disagreed to that assertion but insisted that it might be true with certain factors coming to play to benefit from the credit rating. The rest of the entrepreneurs constituting $16 \%$ were neutral to that assertion. This result was in accordance with Divakaran et al., [5]; the authors indicated that venture capital funding enhanced the credit rating of businesses due to investor's knowledge and technical know-how. The entrepreneurs' view on the requirements of venture capital financing was sought, $58 \%$ of them declared that the requirements were not difficult to meet whiles $34 \%$ indicated that it is cumbersome and did not make venture capital financing appealing to entrepreneurs with $8 \%$ being indifferent to the assertion that venture capital financing requirements were difficult. The entrepreneurs who indicated that the process was cumbersome and requirements were difficult to meet were justified as their reaction corroborate the empirical evidence obtained by Reynolds et al., [13] their study which indicated that less than half a per cent of all nascent entrepreneurs received either venture capital or business angel finance at start-up. In addition it was recorded that less than 2 per cent of respondents had ever raised institutional venture capital in a survey of UK SME's in 2004 as stated by Small Business Service, [14]. It must be noted that even in the developed countries accessing a venture capital is a challenge so within the Ghanaian context where the industry is young and the size of the fund is not huge can be problematic for entrepreneurs to benefit from it as they are expecting.

Figure 1 shows that $54 \%$ of the entrepreneurs indicated that venture capital was a solution to their financial predicaments. Their defense was that venture capital firms did not only provide for the needed funds but also provided assistance to support the growth and expansion of the activities of small businesses. The result aligned with the findings of Muteti [6] who affirmed that lack of finance was a major problem contributing to slow development of small businesses 
in the developing economies. Moreover, Abor and Quartey [8] pointed out that venture capital finance is more suitable for entrepreneurs as many entrepreneurs lacked the preferred collateral demanded by the banks as debt requirement. This is one of the reasons why entrepreneurs saw venture capital as a solution to their financial predicaments. As much as $34 \%$ of the entrepreneurs disagree to the assertion that venture capital was the solution to their financial predicaments. Some of the entrepreneurs pointed out that the size of the business opportunity and the needed funds plus type of industry might affect the access and utilization of the venture capital financing, hence venture capital financing cannot be a total solution to small businesses financial predicaments whether for expansion or start-ups. This finding is consistent with the view of OECD [7] as their study revealed that most of small businesses often heavily relied on straight debt to fulfill their start-up. No wonder the $34 \%$ of the entrepreneurs thought contrary to the assertion. The other $12 \%$ of the entrepreneurs were indifferent to that assertion that venture capital was the solution to the financial predicaments of entrepreneurs.

Entrepreneurs were asked if venture capital funding reduced profit levels. Out of the fifty entrepreneurs $28 \%$ confirmed that it did affect their profit levels, this can be inferred from the literature as most early stage venture-backed start-ups were not able to grow rapidly and be profitable. Hellmann and Puri [21] affirmed that venture capitalist brought professionalism and value adding activities due to his/her involvement in the business. Professionalism comes with its own cost as it can also affect the profitability of the enterprise. Majority of the entrepreneurs constituting $62 \%$ declared that venture capital funding might not be the cause of reduced profit levels if any as operational issues have much weight to affect profits level. This result was in alignment with the study of Engel and Keilbach [20] where they noted that firms that were backed by venture capital financing firms in Germany were more profitability than non-backed venture capital financing. Interestingly $10 \%$ of the entrepreneurs were neutral to that assertion that venture capital funding reduced profit levels.

\section{Impact of Venture Capital Financing on businesses}

Venture growth and performance was tested empirically with data from entrepreneurs' survey conducted in the Kumasi Metropolis. The dependent variable refers to venture growth and performance. The regression analysis (Table 1) shows that four variables employed in the model. The value of the regression coefficient for the intercept described a particular venture growth and performance for the entrepreneurs within the study area, while the remaining coefficient described the impact of each explanatory variable on venture growth and performance.

Table 1. Impact of Venture Capital Financing on businesses

\begin{tabular}{|c|c|c|c|c|c|c|c|}
\hline \multicolumn{8}{|c|}{ Dependent Variable : Venture capital results in growth and performance } \\
\hline \multirow[t]{2}{*}{ Independent variables } & \multirow[t]{2}{*}{$\mathrm{B}$} & \multirow{2}{*}{$\begin{array}{l}\text { Standard } \\
\text { Error }\end{array}$} & \multirow[t]{2}{*}{ Beta } & \multirow[t]{2}{*}{ t-value } & \multirow[t]{2}{*}{ p-value } & \multicolumn{2}{|c|}{ Collinearity statistics } \\
\hline & & & & & & Tolerance & VIF \\
\hline Constant & 3.658 & .095 & & 38.612 & .000 & & \\
\hline Profit (PFT) & $-.205^{* * *}$ & .059 & -.51 & -3.494 & .001 & .141 & 7.080 \\
\hline Innovate (INN) & $.140^{* *}$ & .051 & .36 & 2.870 & .006 & .190 & 5.272 \\
\hline Sale $(S A L)$ & $.362^{* * *}$ & .051 & .94 & 7.082 & .000 & .173 & 5.793 \\
\hline Efficient (EFT) & $.027 *$ & .054 & .07 & .500 & .619 & .156 & 6.411 \\
\hline
\end{tabular}

Source: Author's computation, 2017. Note: R Square $=.903$, Durbin-Watson statistics $=1.046, \mathrm{~F}$ value $=67.060$, F significance $=0.000,{ }^{*} \mathrm{p}<0.1,{ }^{* *} \mathrm{p}<0.05,{ }^{* * *} \mathrm{p}<0.01$

An $\mathrm{R}^{2}$ overall of .903 indicated that 90 percent of the variation in venture growth and performance can be explained by variability in profit, innovation, improved sales and 
operational efficiency. This meant profit, innovation, improved sales and operational efficiency occupy 90 percent in the factors that accounted for the venture growth and performance of the entrepreneurs' for the study in the Kumasi Metropolis of Ghana whiles the other factors accounted for the remaining 10 percent. It can be deduced that the four variables to a greater extend influenced the venture growth and performance of entrepreneurs in Ghana. The Fstatistics had a value of 67 which is highly significant at one percent indicated that the model was fit hence the outcome of the study can be greatly relied upon.

The Durbin-Watson statistics test whether the assumption is tenable, that is testing for serial correlations between errors. The size of the Durbin-Watson statistics depends upon the number of predictors in the model, and the number of observations. Field [33] stressed that values for Durbin-Watson test less than 1 or greater than 3 are definitely a cause for concern. Table 1 indicated that the Durbin-Watson test value is 1.046 which is within the acceptable range. It can therefore be assumed that there was no first order linear autocorrelation in the study multiple linear regression model which meant the assumption had been met. To check for multicollinerality in the multiple linear regression model, the Tolerance should be $>0.1$ (or VIF $<10$ ) for all variables, from Table 1 the collinearity statistics by the figures of the Tolerance and VIF indicated that there was no multicollinearity, which made the model more reliable.

The regression result showed that profit as indicated in Table 1 have a t-value of - 3.494 and a coefficient value of -0.205 with a significant value of $1 \%$. This signified that profit (PFT) had a negative, strong and significant impact on venture growth and performance among entrepreneurs within the Kumasi Metropolis. This implies that for every One Cedi ( $\$ 1$ ) increase in profit of the entrepreneurs, the growth opportunity will decrease by 20.5 pesewas. This provided an evidence for rejecting the null hypothesis that profit has no significant impact on growth and performance of venture growth. This result aligns with Cowling [29] who noted in his study that profits engender growth and growth engenders future profit that allows some firms to continually face increasing returns to scale. It can be inferred that in order to finance growth, the firm must forego profits. The study of Delmar et al. [27] pointed out that firm growth is not static in nature and there may be considerable variation in firm growth over time. They went on to argue that firm's growth pattern is related to age, size and industry. This showed that firm's growth issues goes beyond profitability. It is imperative for entrepreneurs to appreciate the fact that it is good for entrepreneurs to be ambitious but should be careful in pursuing growth strategies at the expense of profits which will be a risky strategy. They should rather focus on profits and reinvesting those profits into the firm for the purposes of sustainability which will serve as a better strategy in the longer term.

Innovation (INN) has a t-value of 2.870 and a coefficient value of 0.140 with a significant value of $5 \%$. This signifies that innovation (INN) has a positive, weak and significant impact on venture growth and performance among entrepreneurs within the Kumasi Metropolis. This implies that for every One Cedi $(\$ 1)$ increase of innovation activities of the entrepreneurs, the growth and performance opportunity will increase by $\$ 1.40$ pesewas. This provides an evidence for rejecting the null hypothesis that innovation by entrepreneurs has no significant impact on growth and performance of venture growth. This result agrees with Gans and Stern [19] where they indicated that venture capital financing strongly impinge on firm's innovation, patenting processes and the influx of technological opportunities. Hence, triggering innovations, along with the firm's professionalization, is another valuable feature of the venture capital funding. In addition several authors' works discussed the relationships between venture capital financing and innovation in terms of several dimensions. Peneder [22] affirmed that innovation and strategy formation and its implementation were by-products of venture capital financing firms. Moreover, Caselli et al. [23] indicated that innovation in terms 
of productivity and creation of patent were added benefits of venture capital financing. Venckuviene, [24] declared that there exist a relationship between venture capital investments and innovation strategy. Kelly and Hankook [25] established that there is empirical evidence suggesting that venture capital is associated with faster growth and an acceleration of the innovation and commercialization process.

Sales $(S A L)$ have a t-value of 7.082 and a coefficient value of 0.362 with a significant value of $1 \%$. This signifies that sales $(S A L)$ have a positive, weak and significant impact on venture growth and performance among entrepreneurs within the Kumasi Metropolis. This implies that for every One Cedi ( $\$ 1)$ increase of sales activities of the entrepreneurs, the growth and performance opportunity will increase by $\$ 3.62$ pesewas. This provides an evidence of rejecting the null hypothesis that sale by entrepreneurs has no significant impact on growth and performance of venture growth. This result confirmed the results obtained by Bloomfield [18], where the study revealed that venture capital backed firms reported high growth sales than non-backed venture capital firms. Kelly and Hankook [25] confirmed that venture capital backed firms outperform their non-venture capital backed counterparts in terms of growth indicators such as higher growth in sales, wages, and employment. Delmar et al., [27] affirmed that sales are one of the preferred indicators as a performance measure of firm's growth. Sales figures were relatively easy to obtain and reflect both short term and long-term changes in the firm. Alemany and Marti [17] in their study also revealed that venture capital funding had a significant and positive effect on growth in sales.

Efficient (EFT) have a t-value of 0.500 and a coefficient value of 0.27 with insignificant at $10 \%$ level of significance. This signifies that efficient (EFT) has a positive, weak and insignificant influence on venture growth and performance among entrepreneurs within the Kumasi Metropolis. This implies that for every One Cedi ( $\$ 1)$ increase in efficiency of the entrepreneurs, the growth and performance opportunity may not have any significant changes. In view of the result with respect to efficiency, this therefore provided an evidence of failing to reject the null hypothesis that efficiency by entrepreneurs has no significant impact on growth and performance of venture growth. This result concurred with the study of Chemmanur et al. [26] indicated that overall efficiency gains generated by venture capital backing arise primarily from improvements in sales, the efficiency gains of high-reputation venture capital backed firms arise also from lower increases in production costs.

The summary results shown in Table 1 are indicating that sales, innovation and efficiency give positive significant impact on venture growth and performance which means the higher the sales, innovation and efficiency, the higher would be the venture growth and performance of entrepreneurs businesses within the Kumasi Metropolis, however, profit has a negative significant impact on venture growth and performance.

\section{CONCLUSION AND RECOMMENDATION}

Venture capital is a private equity market which has formal and informal segments. The formal market consists of financial intermediary firms whiles the informal market is made up of wealthy individuals normally called business angels. This study focuses on the formal venture capital industry where funds are supplied for start-up and expansion of enterprises. The objective of this study was to delve into entrepreneurs' perspective on venture capital financing and its impact on their businesses. Apart from start-up firms, businesses that are in a rapid growth stage need a financial assistance that might be beyond their current resources and network which forces them to search for outside investment which can be extremely challenging. 
The survey revealed that all the entrepreneurs were aware of the existence of venture capital as an alternative source of equity financing. It suggested that there is an opportunity to access venture capital financing by the entrepreneurs as the last resort since they understand the requirements and processes of the venture capital industry. There was evidence that venture capital enhanced the credit rating of entrepreneurs who have accessed venture capital financing. A third of the sampled entrepreneurs affirmed the unattractiveness of venture capital financing due to its cumbersome processes and stricter requirements to access the fund. It is not surprising that few entrepreneurs succeed in raising venture capital; the worrying situation is that some entrepreneurs might not even bother themselves for applying for venture capital knowing that they might not be successful. There was a mixed reaction from the entrepreneurs on venture capital being a solution to their financial predicaments within the Ghanaian context. This suggest that venture capital is not that popular with small businesses and yet to be accepted as a reliable financing option.

The study provided evidence to support that profit has negative significance and strong impact on venture growth and performance. The sustenance of any enterprise primarily is dependent of its making profit, profit per se cannot enhance growth of the business, and a lot of contributing factors come to play such as the vision, the capability, the leadership, the financial prudence and management of resource to make growth possible. Such results should encourage entrepreneurs to work on their profit levels and make sure profits are deployed to areas that will enhance growth of their businesses. Another important point is the positive and significant impact of sales on the venture growth and performance of entrepreneur's businesses. Sales is an important variable in any profit making venture, more sales has the potential and positively to enhance revenue mobilisation and with care utilisation of resources will improves the liquidity stance of the enterprise if cash and accounts receivables are managed well. This can serve as a fulcrum to propel expansion drive of the enterprise which will ultimately lead to growth of the enterprise.

The study affirmed that innovation had a positive, weak and significance impact on venture growth and performance among entrepreneurs. The result must be an eye opener to entrepreneurs irrespective of the size of the business to give a serious attention to innovation in their businesses. Innovation brings about competitive advantage whether in processes or products/services which can enhance venture growth as there is a compelling need for the product or services to consumers/customers to purchase it. The challenge here is innovation usually comes with degree of uncertainty which can deter financiers unless they have a fair knowledge of the technical practicability and market prospects before they will inject funds into the enterprise. Efficiency had a positive, weak and insignificant impact on venture growth and performance among entrepreneurs. The result points to the fact efficiency can be one of the determinants of enterprises sustenance in the longer term. Efficiency is one of the top priorities if businesses are to thrive and grow. A positive outcome of venture capitalist can influence good management of resources thereby affecting the productivity, profitability, competitiveness and innovation.

The paper recommends that the venture capital trust fund must embark on nationwide educational drive by engaging the business communities on its operations. This will help to sensitize the entrepreneurs to appreciate the works and demands of the venture capital trust fund for better opportunity for them to access the venture capital finance. The government must show real commitments and programmes towards the realisation of private enterprises development.

A limitation to this study is that the sample was in Ghanaian context, whose entrepreneurs may 
be distinct from ones with other geographical/cultural background. Secondly, this paper has solely study the perspectives of entrepreneurs in connection to venture capital financing without getting the opportunity to interview senior staff members from the venture capital trust fund and some key venture capitalist to find out challenges and difficulties they faced with entrepreneurs in accessing the venture capital fund. This study offers future research suggestion to delve into the operational activities of the venture capital trust fund and its impact on businesses with financial support and its performance. The extension to the study will be on government commitments and programmes towards the realisation of private enterprises development.

Obtaining equity capital from a venture capitalist is not easy because venture capitalists are selective in their investments and only choose to invest in those companies that they believe have the potential to generate very high returns. The study prescribes generic practices that will aid better chance of accessing venture capital and how to develop venture capital industry in an emerging industry:

- Entrepreneurs must probe venture capital investors on their motives, goals, track records, personnel and overall credibility if they can serve the purpose as equity partner.

- Entrepreneurs must communicate the goals of their new ventures clearly to potential venture capital investors.

- For entrepreneurs to be successfully in raising venture capital finance, they must create a business proposal with a well-articulated product/market opportunity that will have a sufficient competitive advantage and probable exit strategy within three to five years and a detailed plan to achieve the exit conditions.

- It is important for entrepreneurs to have a fair understanding of venture capitalists decision models that help them decide on which companies to invest in and which not to. This can assist them in knowing whether they are attractive to venture capital investments, what potential changes they need to make in order to become attractive, and what information venture capitalist evaluate in their investment decisions.

- The performance of the venture capital industry is influenced by its size, diversity, and competence. This is where governments must establish and develop the venture capital industry through the establishment of institutional infrastructure, supplying capital for venture capital funds, financing early-stage investments and fostering the demand for venture capital.

\section{References}

1. McKaskill, T. (2009). Raising Angel \& Venture Capital Finance. Breakthrough Publications. Melbourne.

2. Butler, D. (2006). Enterprise Planning and Development: Small business start-up survival and growth. Butterworth-Heinemann. Oxford, UK.

3. Hatten, T.S. (2012). Small Business Management: Entrepreneurship and Beyond. $5^{\text {th }}$ Edition. South Western CENGAGE Learning Mason, OH, USA.

4. Longenecker, J.G., Moore, C.W., Petty, J.W., and Palich, L.E., (2008). Small Business Management Launching and Growing Entrepreneurial Ventures. 14 ${ }^{\text {th }}$ Edition. Thomson South-Western

5. Divakaran, S., McGinnis, P. J., and Shariff, M., (2014). Private Equity and Venture Capital in SME's in Developing Countries: The Role of Technical Assistance. Policy Research Working Paper 6827: 1-32 World Bank

6. Muteti, J.K. (2007). Small Enterprises Development in Kenya: Opportunities and Challenges. Eastern African Journal of Humanities and Sciences. (June): 1-20.

7. OECD (2015). New Approaches to SME and Entrepreneurship Financing: Broadening the Range of Instruments. OECD Publishing, Istanbul. 
8. Abor, J. and Quartey, P. (2010). Issues in SME Development in Ghana and South Africa. International Research Journal of Finance and Economics. Issue 39: 218-228

9. Landstrom, H. (2007). Handbook of Research on Venture Capital. Edward Elgar Publishing Limited. Cheltenham

10. Bürgel, O., Fier, A., Licht, G. and Murray, G.C. (2004). The Internationalization of Young High-Tech Firms, ZEW Economic Studies 22, Mannheim: Physica-Verlag.

11. Auerswald, P.E. and Branscomb, L. M., (2003). Start-ups and Spin-offs. The Role of the Entrepreneur in Technology-Based Innovation,' in David Hart (ed.), The Emergency of Entrepreneurship Policy: Governance, Start-Ups, and Growth in the Knowledge Economy, Cambridge, UK: Cambridge University Press.

12. BVCA (2006), Report of Investment Activity 2005. London: British Venture Capital Association.

13. Reynolds, P.D., Bygrave, W.D., Autio, E., Cox L. W. and Hay, M. (2003). Global Entrepreneurship Monitor, 2002 Executive Report, Wellesley and London: Babson College and London Business School.

14. Small Business Service (2005). Results from the 2004 Annual Small Business Survey: Financing the Business, London: Small Business Service.

15. European Commission (2006). Report of the Alternative Investment Expert Group: Developing European Private Equity, Brussels: Commission of the European Communities.

16. European Venture Capital Association (2002). Survey of the Economic and Social Impact of Venture Capital in Europe (June). European Private Equity \& Venture Capital Association. Zaventem, Belgium.

17. Alemany, L. and Marti, J. (2005). Unbiased estimation of economic impact of venture capital backed firms. Working Paper March 2005. EFA 2005 Moscow Meetings Paper. http://dx.doi.org/10.2139/ssrn.673341

18. Bloomfield, S. (2008). Venture Capital Funding: Practical guide to raising finance. $2^{\text {nd }}$ Edition. Kogan Page. London

19. Gan, J.S. and Stern, S. (2003). The Product Market for Ideas: Commercialization Strategies for Technology Entrepreneurs. Research Policy, 32: 333-350

20. Engel, D. and Keilback, M. (2007). Firm Level Implication of Early Stage Venture Capital Investments: an Empirical Investigation. Journal of Empirical Finance, 14(2): 150-167.

21. Hellmann, T. and Puri, M. (2002). Venture capital and the professionalization of start-up firms: Empirical evidence. Journal of Finance, 57(1): 169-197.

22. Peneder, M. (2010). The impact of venture capital on innovation behaviour and firm growth. Venture Capital, 12 (2): 83-107.

23. Caselli, S., Gatti, S. and Perrini, F. (2009). Are Venture Capitalists a Catalyst for Innovation? European Financial Management, 15(1): 92-111.

24. Venckuviene, V. (2014). Building of innovation capacity in venture capital backed companies: qualitative research approach. Business Management Dynamics., 3(10): 59-68.

25. Kelly, R. and Hankook, K. (2013). Venture Capital as a Catalyst for High Growth. http://www.ic.gc.ca/eic/site/eas-aes.nsf/eng/h_ra02218.html, Ottawa: Industry Canada.

26. Chemmanur, T.J., Krishnan, K. and Nandy, D. K., (2011). How does venture capital financing improve efficiency in private firms? A look beneath the surface. Review of Financial Studies, 24 (12): 4037-4090.

27. Delmar, F., Davidsson. P. and Gartner, W.B. (2003). Arriving at the high-growth firm. Journal of Business Venturing 18(2): 189-216.

28. Markman, G. D. and Gartner, W. B. (2002). Is Extraordinary Growth Profitable? A Study of Inc. 500 HighGrowth Companies. Entrepreneurship Theory and Practice, 27(1): 65-75.

29. Cowling, M. (2004). The Growth - Profit Nexus. Small Business Economics, 22(1): 1- 9.

30. Ghana Statistical Services (2013). Millennium Development Goals in Ghana, 2010 Population \& Housing Census Report. Ghana Government

31. De Vaus, D.A. (2002). Surveys in Social Research. $5^{\text {th }}$ Edition. Allen \& Unwin. Crows Nest

32. Bethlehem, J. (2009). Applied Survey Methods: A Statistical Perspective. John Wiley \& Sons, Inc. New York. 
Adusei, C., \& Isaac, T. K. (2017). Venture Capital Financing: Perspective of Entrepreneurs in an Emerging Economy. Archives of Business Research, $5(8), 108-122$

33. Field, A. (2009). Discovering Statistics Using SPSS. $3^{\text {rd }}$ Edition. SAGE Publications Ltd. London

34. Leech, N., Barrett, K. and Morgan, G.A. (2005). SPSS for Intermediate Statistics: Use and Interpretation. $2^{\text {nd }}$ Edition. Lawrence Erlbaum Associates, Inc. London. 